\title{
Impact on Enhancing Livelihoods Opportunities in (MGNREGS) in Annagramam Block, Cuddalore District, Tamil Nadu
}

\author{
G. Jayasaravanan ${ }^{1}$ and P. Murugesan ${ }^{2}$ \\ ${ }^{1}$ Ph.D. Scholar, ${ }^{2}$ Assistant Professor, Centre for Rural Development, Annamalai University, Tamil Nadu, India \\ E-Mail: murugesancrd@gmail.com, jayasaravanancrd@gmail.com
}

\begin{abstract}
The MGNREGS 2005 offered some basic employment for marginalized groups; it did not provide substantial help to the most vulnerable. However, there was some evidence of small but significant shifts in labour relations. Higher wages, more opportunities for work, better implementation and a greater recognition of the care giving responsibilities of women will be required for this policy to fully meet its goals. , irregularities are usually reported when money is involved and the transaction is between officials who have the power to control over the Scheme, and the poor unemployed labourer who would be willing to accept whatever is due to them. However, if the Scheme is implemented efficiently and effectively, it ensures the following outcomes namely: (i), that the employment guarantee would not merely provide relief at the times of distress, it would also be a move towards long-term drought and flood-proofing of Indian agriculture; (ii), this would be a more effective instrument for reducing poverty because the impact of growth on poverty is higher in areas where social infrastructure is more developed; (iv) the number of people depending on the Scheme would steadily decline over time. As the conditions of their farms improves, people will no longer to look for work under MGNREGS; (v) the expenditure incurred on the employment guarantee would be non-inflationary because it will spur agricultural growth upon whose foundation a whole range of sustainable livelihoods could be built; and (Vi) by fuelling successive rounds of private investment, it will also set up a multiplier of secondary employment Opportunities. Hence, the present study is geared towards an in-depth impact of Enhancing Livelihoods Opportunities in MGNREGS.
\end{abstract}

Keywords: Poverty, Employment, Wage Rate, Implementation, MGNREG

\section{INTRODUCTION}

The Mahatma Gandhi National Rural Employment Guarantee Scheme (MGNREGS) has positive impact on empowerment and employment pattern of women in recent years. It aims at enhancing livelihood security by providing at least 100 days of guaranteed wage employment in a financial year to every rural household especially for women. Women participation has increased significantly and perceived it giving them a sense of independence and security. Country should be alerted with proper education and also they should be entrusted with all sorts of works as per their physical capability". Women are needed part of the world. They play important role in the growth of the society as well as the country. The definition of women is actually different for different persons but there is an essential base that cannot change regardless of nationality, caste, color, profession etc., when women support to empower themselves the whole society benefits and families are healthier (Neha et al. 2012). Therefore, it is very important to empower women. The Empowerment of women refers to the influence of decision making of their own. The word "empower has become equal with the word women". MGNREGS is the most significant act in the history of Indian polity in many ways like grass-root level participation of every citizen and beneficiary through democratic process, multi-layered social audit and transparency mechanism by involvement of civil society, comprehensive planning at village level towards sustainable and equitable development etc. Important salient feature of the Act is to improve the quality of life of rural people who are vulnerable to out-migration in search of daily wage employment by channelizing the wage workforce towards developmental activities at the village level itself. Landless women in Tamil Nadu were particularly articulate about their challenges with MGNREGS. While the participants confirmed that the official upper wage limit was Rs. 148, the work required to earn that wage was based on what a man can complete in a day, despite the fact that the majority of MGNREGS workers were women (Dinesh 2012). Because the work was paid according to what was accomplished, women tended to get paid less because they did not get as much done. There were two reasons for this. First, they found the work difficult, particularly in cases where they were digging, and were unable to complete the required digging work. Second, women indicated that they had to work around the schedules of their children, and so women with children tended to work a shorter day (Rahul et al. 2016).

The implementation of MGNREGS seemed to provide some labourers with more power, thus influencing labour relations in ways that were advantageous for marginalized workers, even when MGNREGS wages were lower than those provided through private employers. However, the hierarchy of social and gender relations appeared to remain intact within MGNREGS (Suman et al. 2015). One participant in this group said: 'Labourers have started to demand whatever they feel like, and the wages are becoming different for each type of work, which is becoming an issue (Bhupal 2011). The farmers have to pay whatever they demand or else they will have no one to work in their fields.' Another comment from this group indicated the same: 'The labourers have an upper hand now'. 
In Tamil Nadu, the policy-makers talked about how labourers and farmers could not agree on labour conditions since MGNREGS came in. Labourers could only work on private land in Tamil Nadu through MGNREGS if they were building farm ponds (Susmita 2017). Landowners could hire themselves and workers through MGNREGS to build ponds on private land. There was no indication from the focus group participants that MGNREGS wages acted as a price floor or impacted private wages in Tamil Nadu. However, due to MGNREGS, labourers demanded payment on a weekly basis.

\section{REVIEW OF LITERATURE}

Adeppa (2014) this study reveals the National Rural Employment Guarantee Act (NREGA) is one of the most progressive legislations enacted since independence. Its significance is evident from a variety of perspectives. Data from the official site of the government show that share of work days going to women in NREGA has been on the rise. On the whole it was 368 million (40 per cent) in 2006-07, 475 million (44 per cent) in 2007-08, 1,036 million (47.8 per cent) in 200809 ; 1,364 million (48.1 per cent) in 200910, in 2010-11, 1227 [48\%] and in 2011-12 (up to December 2011) 598 (49\%). In understanding the actual outcomes from NREGA we need to understand the nature of local dynamics, power struggles and dominance.

Thomas (2013) this article is based on the findings of a study on evaluation of the NREGA scheme, intended to assess the impact of this scheme on the overall quality of life of its beneficiaries by gauging different parameters associated with the improvement of overall quality of life of people such as impact on income - earning levels of each household, expenditure on food and non-food items, expenditure on education, household and cultivable assets creation by the beneficiaries, impact on social life, recreational activities and impact on distress out migration. This study also captured the views and feed-back of the beneficiaries on various faucets of implementation of the scheme at grass root level right from the stage of issue of job cards till the payment of wages, social audit etc.

Jawed (2012) attempts to examine and assess the environmental implications of the activities implemented under the MGNREGS. He considered that an ecological act is one of the best features of the MGNREGA as it designates a balance between human action and natural resources creating sustainable economic security through green jobs. The MGNREGS must be strengthened and revamped to provide not just wages for work done but work that will make regeneration possible. The author validates that assets created under MGNREGA have been useful and have contributed towards natural resource regeneration. Since MGNREGA is an ecological Act, it was suggested to set up a biological hedge that grows by the year and not regenerate like sea walls made of stone boulders.

Jeans (2005) in his article entitled "Mahatma Gandhi National Rural Employment Guarantee Act: Promise and
Demise" discussed the pros and cons of the then proposed Act he expresses three common fears. One is that the money will be wasted due to widespread corruption. The second fear is that Employment Guarantee Act will lead to financial bankruptcy. The third fear was that the government will get entangled in endless litigation, as holders of aggrieved labourers take the local authorities to court. To dispense these fears, however, he said that the proposed Act aimed at empowering the disadvantaged, and included extensive safeguards against and dereliction of duty from the concerned authorities.

Jyoti (2012) in the paper "Critical study of MGNREGS: Impact and women's participation" confirmed that the scheme helped women to override their weak position in labor market and get alternative employment.

Subhabrata (2009) in his article on "NREGA in west Bengal: Success and Challenges" discusses some of the important challenges that plague the scheme. The first relates to corruption and leakages.Fraud in muster rolls and embezzlement of government funds are rampant. Second problem relates to variation in wages. The Act stipulates that labourer under the NREGA is entitled to minimum wages, (Rs.73). However; major interstate variations are noticeable in average wage-cost per man-day i.e. average wage rate in rupees per day. It is true corruption and lack of adequate preparation in implementing NREGS has led to some setbacks. But these slippages do not reduce the landmark legislation to irrelevance.

Vinita et al. (2013) analyze the relevance of MGNREGS on women empowerment in their study in Rohtak district of Haryana with 250 respondents through a field survey. Significant benefits reported by the study includes success in raising the level of employment and income of the rural household women, thereby enhancing their purchasing power, satisfaction and confidence etc. 95 percent of the beneficiaries believe that the program enhanced their credit worthiness and 78 percent women believe that they could start saving money only because of the MGNREGS. 76 percent respondents said that they spent wages on regular food and consumer goods.

Kabita Borah and Rimjhim Bordoloi (2014) in the article "MGNREGA and its Impact on Daily Waged Women Workers: A Case study of Sonitpur District of Assam." Concluded that MGNREGA has increased and diversified the contributions that women made by putting cash earnings in women's hands. Women are attending gram-sabha, speaking out in the meetings and their capacity of interaction increased.

Siddhartha and Anish Vanaik (2008) in his essay on "CAG Report on NREGA: Fact and Fiction" presented different aspects of the CAG report that have either been insufficiently emphasized or ignored altogether, so far, along with an appraisal of the strengths and weaknesses of the report. They argue that the report of CAG is half hearted performance audit. They further argue that the report has 
little to say about actual socioeconomic outcomes, whether it is the impact of NREGA on poverty, or on women's empowerment, or on agricultural productivity. They suggest that NREGA outcomes ought to be assessed in terms of the socio-economic impact on the lives of people.

\section{OBJECTIVES OF THE STUDY}

1. Study the socio-economic study of the sample beneficiaries

2. Evaluate the impact of the enhancing livelihood opportunities of the MGNREGS beneficiaries

\section{METHODOLOGY}

For the detailed and further insight into the topic, the best suited Research Design would be Descriptive Research Design. I have opted to take the descriptive research design as the body of information available is matured enough and is also more structured. This also helps in understanding the characteristics of the situation.

\section{A. Sample Design}

The sampling method to be used is Non-Probability Sampling: Convenient or Accidental sampling. This method of sampling helps the researcher to collect the sample at convenience and is more suitable for descriptive study.

\section{B. Sample Size}

The Cuddalore District in Tamilnadu consists of 13 blocks. This study was carried out in Annagramam block. This block is identified based on the high level MGNREGS Employment of present over there and partially in terms of Block office as available. From the above mentioned identified block 6 Panchayats have been selected. Further, the above mentioned Panchayats 3 villages have been selected. 15 respondents have been identified from each village and total number of samples selected for the present study was 270 .

\section{Sources of data Collection}

1. Primary source of data: collected when having direct discussion with the beneficiaries targeting on the research

2. Secondary source collected through Panchayat Office, Block Development Office, District statistical office and articles, journals etc.

Table I Respondents Perception On The Impact Of The Scheme On ENhancing LiVElihood Opportunities

\begin{tabular}{|c|c|c|c|c|c|c|c|c|c|c|c|c|c|c|c|c|c|c|c|c|c|c|}
\hline \multirow{4}{*}{ 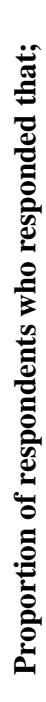 } & \multicolumn{6}{|c|}{ Ezhumedu Panchayat } & & \multicolumn{6}{|c|}{$\begin{array}{c}\text { Keezh Kavarapattu } \\
\text { Panchavat }\end{array}$} & & \multicolumn{6}{|c|}{ Kongarayanur Panchayat } & \multirow[b]{3}{*}{ 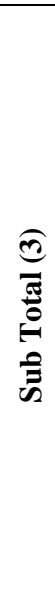 } & \multirow[b]{3}{*}{ 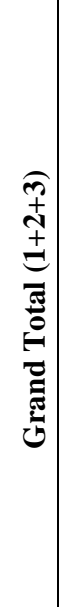 } \\
\hline & \multicolumn{2}{|c|}{$\begin{array}{l}\text { Highest } \\
\text { two } \\
\text { Villages }\end{array}$} & \multicolumn{2}{|c|}{$\begin{array}{c}\text { Middle } \\
\text { two } \\
\text { Villages }\end{array}$} & \multicolumn{2}{|c|}{$\begin{array}{c}\text { Least } \\
\text { two } \\
\text { Villages }\end{array}$} & \multirow[b]{2}{*}{ 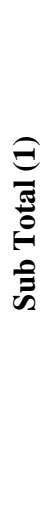 } & \multicolumn{2}{|c|}{$\begin{array}{l}\text { Highest } \\
\text { two } \\
\text { Villages }\end{array}$} & \multicolumn{2}{|c|}{$\begin{array}{c}\text { Middle } \\
\text { two } \\
\text { Villages }\end{array}$} & \multicolumn{2}{|c|}{$\begin{array}{c}\text { Least } \\
\text { two } \\
\text { Villages }\end{array}$} & \multirow[b]{2}{*}{ 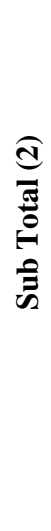 } & \multicolumn{2}{|c|}{$\begin{array}{l}\text { Highest } \\
\text { two } \\
\text { Villages }\end{array}$} & \multicolumn{2}{|c|}{$\begin{array}{c}\text { Middle } \\
\text { two } \\
\text { Villages }\end{array}$} & \multicolumn{2}{|c|}{$\begin{array}{l}\text { Least two } \\
\text { Villages }\end{array}$} & & \\
\hline & 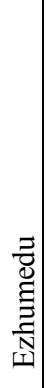 & 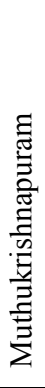 & 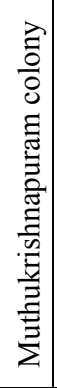 & 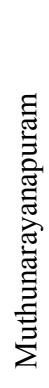 & 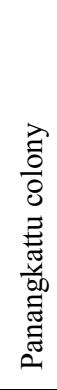 & 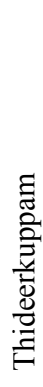 & & 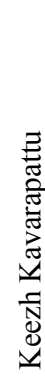 & 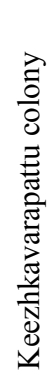 & 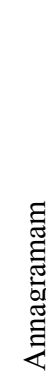 & 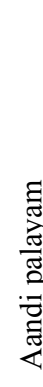 & 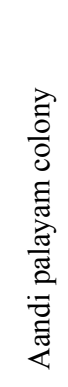 & 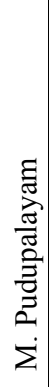 & & 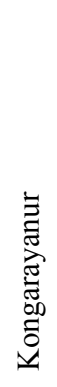 & 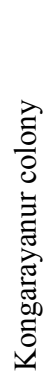 & 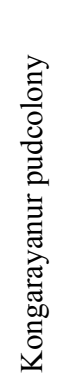 & 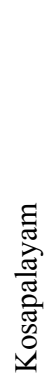 & 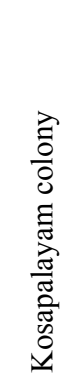 & 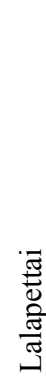 & & \\
\hline & $\dot{\dot{Z}}$ & $\dot{\mathbf{z}}$ & $\dot{0}$ & $\dot{\mathbf{z}}$ & $\dot{0}$ & $\dot{\mathbf{z}}$ & $\dot{\mathbf{Z}}$ & $\dot{8}$ & $\dot{0}$ & $\dot{\mathbf{z}}$ & $\dot{\mathbf{z}}$ & $\dot{\mathbf{z}}$ & $\dot{8}$ & $\dot{0}$ & $\dot{\mathbf{z}}$ & & $\dot{0}$ & $\dot{\mathbf{z}}$ & $\dot{\mathbf{z}}$ & $\mathbf{Z}$ & $\dot{z}$ & $\dot{z}$ \\
\hline$\stackrel{*}{\ll}$ & 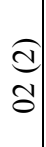 & $\begin{array}{l}\infty \\
\dot{0} \\
0\end{array}$ & $\begin{array}{l}\underset{\hat{f}}{\dot{i}} \\
\vec{e} \\
\vec{v}\end{array}$ & 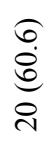 & $\begin{array}{l}\sqrt{n} \\
2 \\
=\end{array}$ & $\begin{array}{l}\hat{F} \\
\dot{0} \\
= \\
=\end{array}$ & 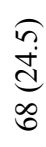 & 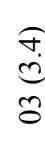 & 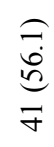 & 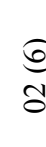 & $\begin{array}{l}n \\
\text { 文 } \\
n\end{array}$ & $\begin{array}{l}\infty \\
\infty \\
\infty \\
\infty \\
0 \\
0\end{array}$ & $\begin{array}{l}6 \\
\substack{0 \\
0 \\
0}\end{array}$ & $\begin{array}{l}\tilde{n} \\
\cdots \\
\infty \\
\infty \\
\infty\end{array}$ & 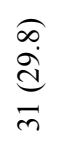 & & $\begin{array}{l}\tilde{n} \\
\text { के } \\
\text { ñ }\end{array}$ & $\underset{n}{\stackrel{E}{E}}$ & 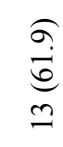 & $\begin{array}{l}2 \\
\pm\end{array}$ & & 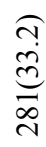 \\
\hline$\stackrel{*}{\sim}$ & 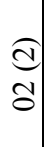 & 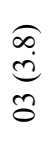 & $\begin{array}{l}\hat{E} \\
\dot{\vec{e}} \\
\vec{v}\end{array}$ & 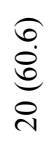 & $\begin{array}{l}\sqrt{n} \\
= \\
=\end{array}$ & $\begin{array}{l}\hat{F} \\
\infty \\
0 \\
=\end{array}$ & 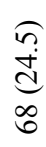 & $\underbrace{\stackrel{f}{0}}_{\tilde{\theta}}$ & $\begin{array}{l}\overparen{7} \\
\dot{0} \\
\qquad \\
7\end{array}$ & $\begin{array}{l}0 \\
\sigma\end{array}$ & $\begin{array}{l}n \\
\text { in } \\
\text { in }\end{array}$ & $\begin{array}{l}2 \\
\infty \\
\infty \\
\infty \\
0 \\
0\end{array}$ & $\begin{array}{l}6 \\
0 \\
0 \\
0 \\
0 \\
0\end{array}$ & $\begin{array}{l}\tilde{n} \\
\infty \\
\infty \\
\infty\end{array}$ & $\begin{array}{l}\infty \\
\stackrel{\infty}{d} \\
\frac{m}{m}\end{array}$ & $\hat{o}$ & 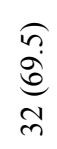 & 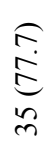 & 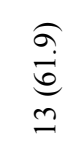 & $\begin{array}{l}\stackrel{\theta}{\Xi} \\
\pm\end{array}$ & 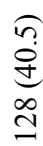 & 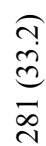 \\
\hline 艺 & 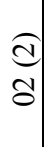 & 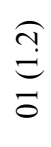 & $\begin{array}{l}\overparen{\Xi} \\
\stackrel{ \pm}{ \pm} \\
\pm\end{array}$ & $\underset{n}{\mathscr{n}}$ & 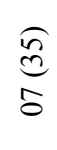 & $\frac{\substack{n \\
0}}{0}$ & 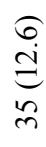 & $\begin{array}{r}\text { กี } \\
\text { ป }\end{array}$ & $\begin{array}{l}\underset{0}{0} \\
\stackrel{d}{2} \\
=\end{array}$ & $\stackrel{0}{0}$ & $\begin{array}{l}\text { తิ } \\
\text { वे }\end{array}$ & 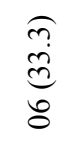 & 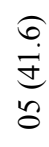 & 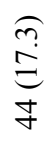 & 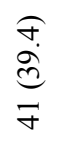 & 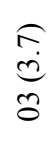 & 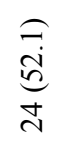 & 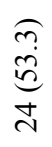 & 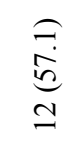 & $\begin{array}{l}7 \\
\text { in } \\
\cong\end{array}$ & 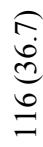 & $\begin{array}{l}\overparen{\overbrace{}} \\
\approx\end{array}$ \\
\hline
\end{tabular}




\section{With the Implementation of the MGNREGS}

1. The creation of community assets under the scheme has enhanced the agricultural activities of their area, hence, livelihood opportunities of their household has enhanced.
2. They got work under the scheme, in their area and even can migrate for work to other places, hence, livelihood opportunities of their household has enhanced.

3. Their household feels more secure or livelihood with the guarantee of 100 days of employment in every financial year.

TABLe Ii Factors Enhancing Livelihood Opportunities In The Study AReA With The IMPLementation Of The MgnREgS

\begin{tabular}{|c|c|c|c|c|}
\hline Independent Variable & Coefficient & Standard & $\mathbf{T}$ & $\begin{array}{c}\text { Level of } \\
\text { Significant }\end{array}$ \\
\hline $\begin{array}{l}\text { With the creation of community assets under the scheme the } \\
\text { agricultural activities of their area has enhanced, hence, livelihood } \\
\text { opportunity of their household has enhanced }\left(\mathrm{x}_{1}\right)\end{array}$ & .967 & .007 & 137.407 & \# \# \\
\hline $\begin{array}{l}\text { They hot work under the scheme, in their area and even can } \\
\text { migrate for work to other places, hence, their employment } \\
\text { opportunity has enhanced }\left(\mathrm{x}_{2}\right)\end{array}$ & .967 & .007 & 137.407 & \# \# \\
\hline $\begin{array}{l}\text { Their household feels more secure for livelihood with the } \\
\text { guarantee of } 100 \text { days of employment in every financial year }\left(\mathrm{x}_{3}\right)\end{array}$ & .032 & .008 & 4.496 & \# \# \\
\hline
\end{tabular}

$\mathrm{N}=846, \mathrm{R} 2=.979, \mathrm{~F}=19971.266$, \# \# Highly Significant, NS $=$ Not Significant

Multiple Regression Model

$\wedge$

$\mathrm{Y}=.999+.967 \times 1+.967 \times 2+.032 \times 3$

\section{E. Impact on Enhancing Livelihood Opportunities}

The principal objective the Scheme is to enhance the livelihood security of the households in rural areas. With this view, opinion was sought from the beneficiaries in the study area and their perceptions are presented in table I. the study revealed that a vast majority of the respondents (5588 percent) in the Gram Panchayat where 100 days of employment were provided in every financial year, the agricultural activities of their area was enhanced resulting in livelihood opportunity for them. A little less than 40 percent have expressed similar views in the remaining seven Gram Panchayats.

Again the majority of the respondents (55-88.8 percent) in the 11 Gram Panchayats where 100 days of employment were provided stated that they got work under the Scheme in their area itself and they can even migrate for work in other places. So employment opportunity has been enhanced. Further, in the study area only in four Gram Panchayats, the majority of the respondents (52.1-60 percent) perceived the security of livelihood with the guarantee of 100 days of employment in every financial year. In the remaining 14 Gram Panchayats, only 2-37 percent of the respondents felt secure about their livelihood met the guarantee of 100 days of employment.

Application of multiple regression analysis presented in Multiple Regression Model table 1 revealed that coefficient of determination $\left(\mathrm{R}^{2}\right)=0.999$, indicating that the three independents variables considered for the study explained 99 percent of the total variation in the influence of the Scheme on enhancing the livelihood opportunities. The result inferred from this is that independent variables namely. with the creation of community assets under the
Scheme the agricultural activities of their area has been enhanced resulting in livelihood opportunity for them $\left(\mathrm{x}_{1}\right)$, they got work under the Scheme in their area end can even migrate for work to other places, hence, their employment opportunity has been enhanced $\left(\mathrm{x}_{2}\right)$ and their household feels more secure about livelihood with the guarantee of 100 days of employment in every financial year $\left(\mathrm{x}_{3}\right)$ are highly significant in enhancing the livelihood opportunities in the study area.

\section{CONCLUSION}

The Impact of MGNREGS, in terms of the implementation process, operationalisation of the Scheme, workers' participation, utilization of funds, benefits to the beneficiaries and community assets created exhibit a mixed picture. However, this is an imperative need for the programme to include the entire agricultural activities anti operationalise them in the area. There is a need to make the Scheme more effective and efficient to facilitate removal of rural poverty and reduction of socio-economic backwardness in the present changing environment. It is essential to ensure and secure their entitlement under the Act. Also, ensuring 100 days of employment under MGNREGS, works on demand, minimum wages, payment within 15 days and provision of essential worksite facilities will in reality enhance the benefits of the programme. The implementing authorities should not deny the workers' statutory rights and should pay unemployment allowance if work is not provided within 15 days. Rural workers must be educated on MGNREGS. Removal of administrative irregularities 'in the Scheme is the need of the hour. The workers in 3 gram Panchayats for whom 100 days of employment were provided stated that they got work under the scheme, in their area and even can migrate for work to other places, hence, their employment opportunity has can migrate for work to other places, hence, their employment opportunity has been enhanced. Application of multiple regression analysis reveals significance in enhancing the livelihood opportunities in the study area because of the implementation of the MGNREGS. 


\section{REFERENCES}

[1] Adeppa. D. (2014, March). Implementation and Impact of MGNREGS: A Study of Anantapuramu District of Andhra Pradesh. International Multidisciplinary Research Journal, 3(2).

[2] Arora, Vinita, Kulshreshtha, L. R., \& Upadhyay, V. (2013, April). Mahatma Gandhi National Rural Employment Guarantee Scheme: A unique scheme for Indian rural women. International Journal of Economics Practices and Theories, 3(2), e-ISSN 2247-7225.

[3] Jawed, Akhtar, S. M. (2012, June). MGNREGS: A Tool for Sustainable Environment. Kurukshetra, 60(8), pp.38-41.

[4] Jeans, Dreze. (2005, May). Employment Guarantee Act: promise and demise", Kurukshetra, 45(5), 9-30.

[5] Jyoti, Poonia. (2012, 9 Jan-Dec,). Critical study of MGNREGS: Impact and women's participation. International Journal of Human Development and Management Sciences, 1(1).

[6] Kabita, Borah \& Rimjhim, Bordoloi. (2014, Jul-Aug.). MGNREGA and its Impact on Daily Waged Women Workers: A Case study of Sonitpur District of Assam. IOSR Journal of Economics and Finance, (IOSR-JEF), 4(4), 40-44.

[7] Rahul, Bahuguna, Akhilesh, Chandra, Pandey. \& Vishal, Soodan. (2016, Oct). A study on Socio Economic Impact of MGNREGA on Beneficiaries in Rudrapryag District of Uttarakhand- India. International Journal of Management and Applied Science, 2(1).
[8] Saleem Akhtar Farooqi \& Imran Saleem. (2015, March). Mahatma Gandhi National Rural Employment Guarantee Act (MGNREGA) and Empowerment of Women from BPL families in rural areas; A case study of district Aligarh (India). IOSR Journal of Humanities and Social Science, 20(3) 07-16.

[9] Shenbagaraj, P., \& Arockiasamy, S. (2013, April). Impact of MGNREGS on local development: A study of Ottapidaram blocks in Thoothukudi district Tamil Nadu. International Journal of Innovative Research \& Development, 2(4), 2013.

[10] Siddhartha \& Anish Vanaik (2008, June). CAG Report on NREGA: Fact and Fiction. Economic and Political Weekly, 43(5), 39-42.

[11] Subhabrata, Dutta. (2009, Dec). NREGA in west Bengal: Success and Challenges. Kurukshetra, 58(2), 31-33.

[12] Suman Pamecha., \& Indu, Sharma. (2015, Jan.). Socio-Economic Impact of MGNREGA - A Study Undertaken among Beneficiaries of 20 Villages of Dungarpur District of Rajasthan. International Journal of Scientific and Research Publications, 5(1), 2015.

[13] Susmita, Bhattacharyya. (2017). Impact of MGNREGA on Sustainable Livelihood of Women. Journal of Rural and Community Affairs, 2(1), 2017.

[14] Thomas, Bigi. (2013, Oct-Dec). Quality of Life: An Impact Assessment on NREGA Beneficiaries. Journal of Social Welfare \& Management, 5(4), 1832013. 